\title{
PEMBELAJARAN KOOPERATIF, SEBAGAI SALAH SATU MODEL PEMBELAJARAN DI MADRASAH IBTIDAIYYA (MI).
}

\author{
Aceng Jaelani* \\ *Dosen Jurusan PGMI FITK IAIN Syekh Nurjati Cirebon
}

\begin{abstract}
ABSTRAK
Salah satu strategi dan model pembelajaran adalah strategi pembelajaran kooperatif (cooperative learning). Pembelajaran kooperatif merupakan strategi pembelajaran yang akhir-akhir ini menjadi perhatian dan dianjurkan para ahli pendidikan untuk digunakan. Ada dua alasan mengapa kooperatif learning menjadi pilihan, pertama, beberapa hasil penelitian membuktikan bahwa penggunaan pembelajaran kooperatif dapat meningkatkan prestasi belajar siswa sekaligus dapat meningkatkan kemampuan hubungan sosial, menumbuhkan sikap menerima kekurangan diri dan orang lain, serta dapat meningkatkan harga diri. Kedua, pembelajaran kooperatif dapat merealisasikan kebutuhan siswa dalam belajar berpikir, memecahkan masalah, dan mengintegrasikan pengetahuan dengan keterampilan. Dan dua alasan tersebut, maka pembelajaran kooperatif merupakan bentuk pembelajaran yang dapat memperbaiki sistem pembelajaran yang selama ini memiliki kelemahan.
\end{abstract}

Kata Kunci : Strategi Pembelajaran, Pembelajaran Kooperatif 


\section{A. Pendahuluan}

Keberhasilan pembelajaran ditentukan oleh berbagai faktor yang menjadi komponen dari proses pembelajaran itu sendiri. Komponen-komponen tersebut adalah di antaranya, guru, tujuan sarana dan strategi atau metode dan model pembelajarannya itu sendiri. Semua komponen itu saling melengkapi dan saling ketergantungan satu dengan yang lainnya. Seorang guru yang kaya akan penguasaan materi umpamanya, tidak akan dapat berhasil mengajar dengan baik kalau hanya mengandalkan kekayaan yang dimilikinya itu, tanpa memparhatikan metoda apa yang akan ia gunakan yang sesuai dengan kondisi siswa yang dihadapinya, demikian dengan yang lainnya..

Dalam sebuah perncanaan pembelajaran yang baik, seorang guru harus mempersiapkan dengan matang skenario pemelajaran yang akan dilakukan di kelasnya nanti. Mulai dari tujuan dan kompetensi yang akan atau harus dicapai dalam pertemuan tersebut, metoda dan alat peraga tertentu yang dibutuhkan, evaluasi yang akan digunakan dan sebagainya, sehingga dengan prosedur persiapan yang terperinci akan membuat seorang guru betul-betul siap mengajar.

Dalam mengajarkan suatu pokok bahasan tertentu harus dipilih model pembelajaran yang paling sesuai dengan tujuan yang akan dicapai. Oleh karena itu dalam memilih suatu model pembelajaran harus memiliki pertimbanganpertimbangan, ini misalnya materi pelajaran, tingkat perkembangan kognitif siswa, sarana prasana atau fasilitas yang tersedia sehingga tujuan pembelajaran yang telah ditetapkan dapat tercapai.

Dengan demikian merupakan hal yang sangat penting bagi para pengajar untuk mempelajari dan menambah wawasan tentang model pembelajaran yang telah diketahui. Karena dengan menguasai model pembelajaran maka seorang guru akan merasakan adanya kemudahan di dalam pelaksanaan pembelajaran di kelas sehingga tujuan pembelajaran yang hendak dicapai dalam proses pembelajaran dapat tercapai dan tuntas sesuai dengan yang diharapkan.

Salah satu strategi dan model pembelajaran adalah strategi pembelajaran kooperatif (cooperative learning). Pembelajaran kooperatif merupakan strategi 
pembelajaran yang akhir-akhir ini menjadi perhatian dan dianjurkan para ahli pendidikan untuk digunakan. Ada dua alasan mengapa kooperatif learningmenjadi pilihan, pertama, beberapa hasil penelitian membuktikan bahwa penggunaan pembelajaran kooperatif dapat meningkatkan prestasi belajar siswa sekaligus dapat meningkatkan kemampuan hubungan sosial, menumbuhkan sikap menerima kekurangan diri dan orang lain, serta dapat meningkatkan harga diri. Kedua, pembelajaran kooperatif dapat merealisasikan kebutuhan siswa dalam belajar berpikir, memecahkan masalah, dan mengintegrasikan pengetahuan dengan keterampilan. Dan dua alasan tersebut, maka pembelajaran kooperatif merupakan bentuk pembelajaran yang dapat memperbaiki sistem pembelajaran yang selama ini memiliki kelemahan (Trianto : $2007: 41$ ).

\section{B. Memahami Model Pembelajaran Kooperatif}

Model pembelajaran adalah salah satu perencanaan atau suatu pola yang digunakan sebagai pedoman dalam merencanakan pembelajaran di kelas atau pembelajaran dalam tutorial dan untuk menentukan perangkat-perangkat pembelajaran termasuk di dalamnya buku-buku, film, komputer dan lain-lain. (Trianto, 2007:5).

Menurut Nurulwati (Trianto, 2007 :10), bahwa maksud dan model pembelajaran adalah kerangka konseptual yang melukiskan prosedur yang sistematis dalam mengorganisasikan pengalaman belajar untuk mencapai tujuan belajar tertentu dan berfungsi sebagai pedoman bagi perancang pembelajaran dan para pengajar dalam merencanakan aktivitas belajar mengajar.

Istilah model pembelajaran mempunyai makna yang lebih luas dari pada strategi, metode atau prosedur. Kardiri dan Nur (2000:9) menyatakan bahwa model pembelajaran mempunyai empat cici khusus yang tidak dimiliki oleh strategi, metode atau prosedur, ciri-ciri tersebut ialah :

1. Secara teoritis model pembelajaran dapat dikembangkan

2. Landasan pemikiran untuk meneapai tujuan pembelajaran yang diharapkan

3. Tingkah laku dalam mengajar supaya model tersebut dapat dilaksanakan dengan berhasil. 
4. Lingkungan belajar yang mendukung sehingga tujuan pembelajaran itu dapat tercapai.

Lasmawan dalam Dimyati, (2006 : 10), menyatakan belajar kooperatif (cooperative learning) adalah suatu model pembelajaran dimana siswa belajar dan bekerja dalam kelompok-kelompok kecil secara kolaboratif yang anggotanya terdiri dan enam orang, dengan struktur kelompok yang bersifat heterogen.

Sedangkan menurut Slavin (Trianto, 2007:50), coopertive learning mengandung pengertian sebagai suatu sikap/perilaku bersama dalam bekerja membantu diantara sesama dalam struktur kerjasama yang teratur dalam kelompok, yang terdiri dari dua orang atau lebih dimana keberhasilan kerja sangat dipengaruhi oleh keterlibatan dari setiap individu dalam kelompok itu sendiri. Sehingga model pembelajaran kooperatif ini memandang keberhasilan dalam belajar bukan semata-mata harus diperoleh dan guru, melainkan bisa juga dan pihak yang terlibat dalam pembelajaran itu yaitu teman sebaya.

Berdasarkan pengertian tersebut, pembelajaran kooperatif merupakan model pembelajaran dengan menggunakan sistem pengelompokan tim kecil, yaitu antara empat satu samapai enam orang yang mempunyai latar belakang kernampuan akademik, jenis kelamin, ras, atau suku yang berbeda (heterogen). Sistem penilaian dilakukan terhadap kelompok. Setiap kelompok akan memperoleh penghargaan (reward), jika kelompok mampu menunjukkan prestasi yang dipersyaratkan. Dengan demkian, setiap anggota kelompok akan mempunyai ketergantungan positif. Ketergantungan semacara itulah yang selanjutnya akan memunculkan tanggung jawab individu terhadap kelompok dan keterampilan interpersonal dan setiap anggota kelompok. Setiap individu akan saling membantu, mereka akan mempunyai motivasi untuk keberhasilan kelompok, sehingga setiap individu akan memiliki kesempatan yang sama untuk memberikan kontribusi demi keberhasilan kelompok.

Trianto (2007 : 44) menyatakan bahwa pembelajaran kooperatif berbeda dengan strategi pembelajaran yang lain. Perbedaan tersebut dapat dilihat dari proses pembelajaran yang lebih menekankan kepada proses kerja sama dalam kelompok. Tujuan yang ingin dicapai tidak hanya kemampuan akademik dalam 
pengertian penguasaan bahan pelajaran, tetapi juga adanya unsur kerja sama untuk penguasaan materi tersebut. Adanya kerja sama inilah yang menjadi ciri khas dan pembelajaran kooperatif.

RE Slavin, $d k k$. (2008) berpendapat bahwa belajar melalui kooperatif dapat dijelaskan dan beberapa perspektif, yaitu perspektif motivasi, perspektif sosial, perspektif perkembangan kognitif, dan perspektif elaborasi kognitif. Perspektif motivasi artinya bahwa penghargaan yang diberikan kepada kelompok memungkinkan setiap anggota kelompok akan saling membantu. Dengan demikian, keberhasilan setiap individu pada dasarnya adalah keberhasilan kelompok. Hal semacam ini akan mendorong setiap anggota kelompok untuk memperjuangkan keberhasilan kelompoknya.

Pembelajaran kooperatif dikembangkan untuk mencapai setidak-tidaknya tiga tujuan pembelajaran, yaitu hasil belajar akademik, penerimaan terhadap keragaman, dan pengembangan keterampilan sosial. Para ahli telah menunjukkan bahwa model struktur penghargaan kooperatif telah dapat meningkatkan penilaian siswa pada belajar akademik dan perubahan norma yang berhubungan dengan hasil belajar. Siswa kelompok atas menjadi tutor bagi kelas bawah, sehingga kelompok atas akan meningkat kemampuan akademiknya, begitu pula dengan kelas bawah. Pembelajaran kooperatif memiliki efek penting dalam penerimaan yang luas terhadap orang yang berbeda menurut ras, budaya, klas sosial, kemapuan maupun ketidakmampuan. Pembelajaran kooperatif memberi peluang kepada siswa yang berbeda latar belakang dan kondisi untuk bekerja saling bergantung satu sama lain atas tugas-tugas bersama, dan melalui struktur penghargaan kooperati, belajar untuk menghargai satu sama lain.

Bekerja dalam kelompok memberi banyak manfaat diantaranya:

a. Memberi tempat pada orang lain

b. Berada dalam kelompok

c. Melakukan hubungan mata

d. Belajar berbicara dengan berbisik

e. Memanggil siswa dengan namanya

f. Mengurangi rasa ingin mengalahkan 
g. Belajar mengambil alih pembicaraan

h. Membentuk rasa berkelompok (swim and sink together)

i. Memberikan kesempatan pada orang lain untu berbicara

j. Mendengarkan dengan seksama.

\section{Elemen-Elemen Dasar Pembelajaran Kooperatif}

Menurut Lie, (2004 31), ada empat elemen dasar belajar kooperatif yaitu:

a. Saling ketergantungan positif

Dalam interaksi kooperatif guru diharapkan dapat menciptakan suasana belajar yang mendorong anak-anak untuk saling berinteraksi dan saling menumbuhkan sikap positif.

b. Interaksi tatap muka

Dalam interaksi positif semua siswa diharapkan saling bertatap muka sehingga mereka dapat melakukan dialog dan dapat mengembangkan komunikasi yang efisien.

c. Akuntabilitas individual

Dalam kelompok belajar kooperatiftiap anggota kelompok dituntut untuk memberikan andil bagi keberhasilan kelompoknya.

d. Keterampilan menjalin hubungan dengan siswa

Dalam pembelajaran kooperatif keterampilan sosial bermanfaat untuk menjalin hubungan dengan siswa lain tentang materi pmbelajaran yang diajarkan dan dilatihkan.

Mulyadiana (Trianto, 2000 : 10), menyatakan bahwa pembelajaran kooperatif sebagai suatu lingkungan belajar, dimana siswa bekerja bersama dalam kelompok heterogen untuk menyelesaikan tujuan bersama. Kemudian Mulyadiana dalam Trianto, (2000 : 11) menyatakan bahwa belajar koopertif adalah cara untuk mengatur belajar di kelas dimana siswa bekerja bersama untuk mencapai tujuan berupa pengetahuan dan keterampilan. Agar pembelajaran kooperatif dapat berjalan secara efektif, unsur-unsur pembelajaran kooperatif yang perlu ditanamkan pada siswa sebagai berikut :

1) Siswa harus memiliki persepsi secara bersama-sama. 
2) Siswa memiliki tanggung jawab terhadap tiap siswa lain dalam kelompoknya dalam mempelajari materi yang dihadapi

3) Siswa harus berpandangan sama sehingga memiliki tujuan yang sama

4) Siswa membagi tugas dan tanggung jawab yang sama dengan anggota kelompok

5) Siswa dilakukan evaluasi atau penghargaan yang akan berpengaruh terhadap evaluasi seluruh anggota kelompok.

6) Siswa akan diminta pertanggungjawaban individual, tentang materi yang dlipelajari dalam kelompok kooperatif.

Menurut Lie (1993), terdapat empat tahapan keterampilan kooperatif yang harus ada dalam model pembelajaran kooperatif yaitu :

1) Forming (pembentukan) yaitu keterampilan yang dibutuhkan untuk membentuk kelompok dan pembentuk sikap yang sesuai dengan norma.

2) Functioning (pengaturan) yaitu keterampilan yang dibutuhkan untuk mengatur aktivitas kelompok dalam menyelesaikan tugas dan membina hubungan kerja sama diantara anggota kelompok.

3) Formating (perumusan) yaitu keterampilan yang dibutuhkan untuk pembentukan pernahaman yang lebih dalam terhadap bahan-bahan yang dipelajari

4) Fermenting (penyerapan) yaitu keterampilan yang dibutuhkan untuk merangsang pernahaman konsep sebelum pembelajaran sehingga diperoleh kesimpulan.

Berdasarkan hasil penelitian Lasmawan dalam Dimyati, (2006) tentang pembelajaraan cooperative learning, menyatakan bahwa belajar kooperatif (cooperative learning) adalah suatu model pembelajaran dimana siswa belajar dan bekerja dalam kelompok-kelompok kecil secara kolaboratif yang anggotanya terdiri dan enam orang, dengan struktur kelompok yang bersifat heterogen. Berdasarkan hasil penelitian diketahui bahwa dengan adanya model pembelajaran 
cooperative learning maka hasil belajar siswa meningkat karena dengan pembelajaran tersebut maka kemampuan siswa meningkat. Hal ini menunjukkan bahwa : "Para siswa memiliki persepsi secara bersama-sama sehingga siswa siswa : memiliki tanggung jawab terhadap tiap siswa yang memiliki pandangan yang sama sehingga guru dapat melakukan evaluasi terhadap anggota kelompok.

Jun'ati dalam Trianto, (2000 : 30) menyatakan bahwa model cooperative learning merupakan strategi yang dirancang dapat memberikan dorongan kepada peserta didik agar bekerjasasama selama berlangsungnya proses belajar sehingga siswa mampu melakukan tugas untuk menjelaskan dengan baik ide-ide yang sulit kepada siswa lainnya (teman sebayanya), sehingga siswa saling membantu memahami konsep-konsep yang sulit dan menumbuhkan kemampuankemampuan bekerjasama, berfikir kritis dan memiliki kemampuan membantu saling membantu.

\section{Karakteristik Pembelajaran Kooperatif}

Menurut Mulyadina (Trianto, 2007 :10), karakteristik pembelajaran kooperatif yaitu :

\section{Pembelajaran Secara Tim}

Pembelajaran kooperatif adalah pembelajaran secara tim. Tim merupakan tempat untuk mencapai tujuan, oleh karena itu, tim harus mampu membuat setiap siswa belajar. Semua anggota tim harus saling membantu untuk mencapai tujuan pembelajaran. Untuk itulah, kriteria keberhasilan pembelajaran yang ditentukan oleh keberhasilan tim.

Setiap kelompok bersifat heterogen : artinya, kelompok terdiri atas anggota yang memiliki kemampuan akademik, jenis kelamin, dan latar belakang sosial yang berbeda. Hal ini dimaksudkan agar setiap anggota kelompok dapat saling memberikan pengalaman, saling memberi dan menerima, sehingga diharapkan setiap anggota dapat memberikan kontribusi terhadap keberhasilan kelompok.

2. Didasarkan pada Manajemen Kooperatif 
Sebagaimana pada umumnya, manajemen mempunyai empat fungsi pokok, yaitu fungsi perencanaan, fungsi organisasi, fungsi pelaksanaan, dan fungsi kontrol. Demikian juga dalam pembelajaran koopiratif fungsi perencanaan menunjukkan bahwa pembelajaran kooperatif memerlukan perencanaan yang matang agar proses pembelajaran berjalan secara efektif. ini misalnya tujuan apa yang harus dicapai, bagaimana cara mencapainya, apa yang harus digunakan untuk mencapai tujuan itu dan lain sebagainya. Fungsi pelaksanaan menunjukkan bahwa pembelajaran kooperatif harus dilaksanakan sesuai dengan perencanaan, melalui langkah-langkah pembelajaran yang sudah ditentukan termasuk ketentuan-ketentuan yang sudah disepakati bersama. Fungsi organisasi menunjukkan bahwa pembelajaran kooperatif adalah pekerjaan bersama antar setiap anggota kelompok, oleh sebab itu perlu diatur tugas dan tanggung jawab setiap anggota kelompok. Fungsi kontrol menunjukkan bahwa dalam pembelajaran kooperatif perlu ditentukan kriteria keberhasilan baik melalui tes maupun nontes.

\section{Kemauan untuk Bekerja Sama}

Keberhasilan pembelajaran kooperatif ditentukan oleh keberhasilan secara kelompok. Oleh sebab itu, prinsip bekerja sama perlu ditekankan dalam proses pembelajaran kooperatif. Setiap anggota kelompok bukan saja harus diatur tugas dan tanggung jawab masing-masing, akan tetapi juga ditanamkan perlunya saling membantu, ini misalnya yang pintar perlu membantu yang kurang mampu.

\section{Keterampilan Bekerja Sama}

Kemauan untuk bekerja sama itu kemudian dipraktikkan melalui aktivitas dan kegiatan yang tergambarkan dalam keterampilan bekerja sama. Dengan demikian, siswa perlu didorong untuk mau dan sanggup berinteraksi dan berkornunikasi dengan anggota lain. Siswa perlu dibantu mengatasi berbagai hambatan dalam berinteraksi dan berkomunikasi, sehingga setiap siswa dapat menyampaikan ide, mengemukakan pendapat, dan memberikan kontribusi kepada keberhasilan kelompok. 
Menurut Mulyadiana (Trianto, 2007 :10), terdapat empat prinsip dasar pembelajaran kooperatif, seperti dijelaskan di bawah ini.

\section{a. Prinsip Ketergantungan Positif (positive interdependence)}

Dalam pembelajaran kelompok, keberhasilan suatu penyelesaian tugas sangat tergantung kepada usaha yang dilakukan setiap anggota kelompoknya. Oleh sebab itu, perlu disadari oleh setiap anggota kelompok keberhasilan penyelesaian tugas kelompok akan ditentukan oleh kinerja masing-masing anggota. Dengan demikian, semua anggota dalam kelompok akan merasa saling ketergantungan.

Untuk terciptanya kelompok kerja yang efektif, setiap anggota kelompok masing-masing perlu membagi tugas sesuai dengan tujuan kelompoknya. Tugas tersebut tentu saja disesuaikan dengan kemampuan setiap anggota kelompok. Inilah hakikat ketergantungan positif, artinya tugas kelompok tidak mungkin bisa diselesaikan ketika ada anggota yang tak bisa menyelesaikan tugasnya, dan semua ini memerlukan kerja sama yang baik dan masing-masing anggota kelompok. Anggota kelompok yang mempunyai kemampuan lebih, diharapkan mau dan mampu membantu temannya untuk menyeesaikan tugasnya.

b. Tanggung Jawab Perseorangan (individual accountability)

Prinsip ini merupakan konsekuensi dan prinsip yang pertama. Oleh karena keberhasilan kelompok tergantung pada setiap anggotanya, maka setiap anggota kelompok harus memiliki tanggung jawab sesuai dengan tugasnya. Setiap anggota harus memberikan yang terbaik untuk keberhasilan kelompoknya : Untuk mencapai hal tersebut, guru perlu memberikan penilaian terhadap individu dan juga kelompok. Penilaian individu bisa berbeda, akan tetapi penilaian kelompok harus sama.

c. Interaksi Tatap Muka (face to face promotion interaction)

Pembelajaran kooperatif memberi ruang dan kesempatan yang luas kepada setiap anggota kelompok untuk bertatap muka saling memberikan informasi dan saling membelajarkan. Interaksi tatap muka akan memberikan pengalaman yang berharga kepada setiap anggota kelompok untuk bekerja sama, 
menghargai setiap perbedaan, rnemanfaatkan kelebihan masing-masing anggota, dan mengisi kekurangan masing-masing. Kelompok belajar kooperatif dibentuk secara heterogen, yang berasal dan budaya, latar belakang sosial, dan kemampuan akademik yang berbeda. Perbedaan semacara ini akan menjadi modal utama dalam proses saling memperkaya antar-anggota kelompok.

\section{d. Partisipasi dan Komunikasi (participation communication)}

Pembelajaran kooperatif melatih siswa untuk dapat mampu berpartisipasi aktif dan berkomunikasi. Kemampuan ini sangat penting sebagai bekal mereka dalam kehidupan di masyarakat. Oleh sebab itu, sebelum melakukan kooperatif, guru perlu membekali siswa dengan kemampuan berkomunikasi. Tidak setiap siswa mempunyai kemampuan berkomunikasi, ini misalnya kemampuan mendengarkan dan kemampuan berbicara, padahal keberhasilan kelompok ditentukan oleh partisipasi setiap anggotanya. Untuk dapat melakukan partisipasi dan komunikasi, siswa perlu dibekali dengan kemampuan-kemampuan berkomunikasi. Misalnya, cara menyatakan ketidaksetujuan atau cara menyanggah pendapat orang lain secara santun, tidak memojokkan, cara menyampaikan gagasan. dan ide-ide yang dianggapnya baik dan berguna.

Keterampilan berkomunikasi memang memerlukan waktu. Siswa tak mungkin dapat menguasainya dalam waktu sekejap. Oleh sebab itu, guru perlu terus melatih dan melatih, sampai pada akhirnya setiap siswa memiliki kemampuan untuk menjadi komunikator yang baik.

Menurut Lie (2005 :32), prosedur pemlelajaran kooperatif pada pninsipnya terdiri atas empat tahap, yaitu : a) penjelasan materi, b) belajar dalam kelompok, c) penilaian dan d) pengakuan tim.

\section{a). Penjelasan Materi}

Tahap penjelasan diartikan sebagai proses penyampaian pokok-pokok materi pelajaran sebelum siswa belajar dalam kelompok. Tujuan utama dalam tahap ini adalah permahaman siswa terhadap pokok materi pelajaran. Pada tahap ini guru memberikan gambaran umum tentang materi pelajaran yang harus 
dikuasai yang selanjutnya siswa akan memperdalam materi dalam pembelajaran kelompok (tim). Pada tahap ini guru dapat menggunakan metode ceramah, curah pendapat, dan tanya jawab, bahkan kalau perlu guru dapat menggunakan demonstrasi. Di samping itu, guru juga dapat menggunakan berbagai media pembelajaran agar proses penyampaian dapat lebih menarik siswa.

b). Belajar dalam Kelompok

Setelah guna menjelaskan gambaran umum tentang pokok-pokok materi pelajaran, selanjutnya siswa diminta untuk belajar pada kelompoknya masingmasing yang telah dibentuk sebelumnya. Pengelompokan dalam pembelajaran kooperatif bersifat heterogen, artinya kelompok dibentuk berdasarkan perbedaan-perbedaan setiap anggotanya, baik perbedaan gender, latar belakang agama, sosial-ekonomi dan etnik, serta perbedaan kemampuan akademik. Dalam hal kemampuan akademik, kelompok pembelajaran biasanya terdiri dan satu orang berkemampuan akademik tinggi, dua orang dengan kemampuan sedang dan satu lainnya dan kelompok kemampuan akademik kurang. Selanjutnya terdapat beberapa alasan lebih disukainya pengelompokan heterogen. Pertama, kelompok heterogen memberikan kesempatan untuk saling mengajar (peer tutoring) dan saling mendukung. Kedua, kelompok ini meningkatkan relasi dan interaksi antar ras, agama, etnis, dan gender. Terakhir, kelompok heterogen memudahkan pengelolaan kelas karena dengan adanya satu orang yang berkemampuan akademik tinggi, guru mendapatkan satu asisten untuk setiap tiga orang. Melalui pembelajaran dalam tim siswa didorong untuk melakukan tukar-menukar (sharing) informasi dan pendapat, mendiskusikan permasalahan secara bersama, memberikan jawaban mereka dan mengoreksi hal-hal yang kurang tepat.

c). Penilaian

Penilaian dalam strategi pembelajaran kooperatif (SPK) bisa dilakukan dengan tes atau kuis. Tes atau kuis dilakukan baik secara individual maupun secara kelompok. Tes individual nantinya akan memberikan informasi kemampuan 
setiap siswa dan tes kelompok akan memberikan informasi kemampuan setiap kelompok. Hasil akhir setiap siswa adalah penggabungan keduanya dan dibagi dua. Nilai setiap kelompok memiliki niai sama dalam kelompoknya. Hal ini disebabkan nilai kelompok adalah nilai bersama dalam kelompoknya yang merupakan hasil kerja sama setiap anggota kelompok.

d). Pengakuan Tim

Pengakuan tim (team recognition) adalah penetapan tim yang dianggap paling menonjol atau tim paling berprestasi untuk kemudian diberikan penghargaan atau hadiah. Pengakuan dan pemberian penghargaan tersebut diharapkan dapat memotivasi tim untuk terus berprestasi dan juga membangkitkan motivasi tim lain untuk lebih mampu meningkatkan prestasi mereka.

\section{E. Keunggulan dan Kelemahan Pembelajaran Kooperatif}

1. Keunggulan pembelajaran cooperatif

Mulyadiana (Trianto, 2000:10) menyatakan bahwa keunggulan pembelajaran kooperatif sebagai suatu strategi pembelajaran di antaranya :

1) Melalui pembelajaran kooperatif siswa diharapkan tidak terlalu berharap pada guru, akan tetapi dapat menambah kepercayaan kemampuan berpikir sendiri sehingga menemukan informasi dan berbagai sumber dan belajar dan siswa yang lain.

2) Pembelajaran kooperatif dapat mengembangkan kemampuan mengungkapkan ide atau gagasan dengan kat-kata secara verbal dan membandingkannya dengan ide-ide orang lain.

3) Pembelajaran kooperatif dapat membantu anak untuk respek pada orang lain dan menyadari akan segala keterbatasannya serta menerima segala perbedaan.

4) Pembelajaran kooperatif dapat membantu memberdayakan setiap siswa untuk lebih bertanggung jawab dalam belajar.

5) Pembelajaran kooperatif merupakan suatu strategi yang cukup ampuh untuk meningkatkan prestasi akadernik dan non akademik. 
6) Melalui pembelajaran kooperatif dapat mengembangkan kemampuan siswa untuk menguji ide dan pemahamannya sendiri, menerima umpan balik.

7) Pembelajaran kooperatif dapat meningkatkan kemampuan siswa menggunakan informasi dan kemampuan belajar abstrak menjadi nyata (riil).

\section{Keterbatasan Pembelajaran Kooperatif}

Mulyadiana (Trianto, 2007 : 16) menyatakan bahwa pembelajaran kooperatif memiliki keterbatasan, di antaranya :

1. Untuk memahami dan mengerti filosofis pembelajaran kooperatif memang butuh waktu karena terdapat perbedaan antara siswa yang memiliki kelebihan dan siswa yang merasa kurang.

2. Ciri utama dari pembelajaran kooperatif adalah bahwa siswa saling bekerjasama dalam memecahkan permasalahan.

3. Penilaian yang diberikan dalam pembelajaran kooperatif didasarkan kepada hasil kerja kelompok.

4. Keberhasilan pembelajaran kooperatif dalam upaya mengembangkan kesadaran berkelompok memerlukan periode waktu yang cukup panjang.

5. Kemampuan bekerja sama merupakan kemampuan yang sangat penting untuk siswa, akan tetapi banyak aktivitas dalam kehidupan yang hanya didasarkan kepada kemampuan secara individual.

\section{F. PENUTUP}

Dari pembahasan tentang pembelajaran kooperatif yang telah dijelaskan di atas, dari berbagai langkah, prosedur, kelemahan dan kelebihan yang terdapat dalam pembelajaran kooperatif, maka jika dikaitkan dengan kenbutuhan pendekatan serta metoda pembelajaran bagi anak yang berada di pendidikan dasar pendekatan atau model pembelajaran kooperatif ini sangat dibutuhkan.

Namun, semuanya terpulang kepada guru sebagai aktor utama dalam sebuah pembelajaran. Kemampuan dan kemauan seorang guru untuk sangat 
menentukan efektif atau tidaknya sebuah pendekatan, metoda ataupunj model dalam pembelajaran. Harapan yang sangat besar dari penulisan ini, semoga para guru di tingkat pendidikan dasar terutama SD dan MI dapat mengembangkan dan mengimplementasikan berbagaio strategi, metoda dan model pembelajaran yang sekaranmg berkembang. Dengan demikian, maka proses pembelajaran di tingkat dasar (SD/MI) dapat menjadi sebuah pembelajaran yang Aktif, Inovatif, Kreatif, edukatif dan Menyenangkan (PAIKEM). Semoga.....

WALLAHU A 'LAM BI AL SHAWWAB 


\section{DAFTAR PUSTAKA}

Dahlan. 1990. Model-model Mengajar (Beberapa Alternatif Interaksi. Belajar Mengajar). Bandung : CV. Dipenogoro.

Dimyati, Mudjiono. 2006. Belajar dan Pembelajaran. Jakarta, Rineka Cipta.

Isjoni. (2009). Cooperative Learning Mengembangkan Kemampuan Belajar Berkelompok. Bandung : Alfabeta.

Kasdi S. dan Nur. 2000. Pengajaran Langsung. Surabaya : University Press.

Kurniawati. 1996. Pengertiankonsep.blogspot.com/ diakases tanggal 22 desember 2009

Lie, A. 2007. Cooperative Learning, Mempraktekan Cooperative Learning di Ruang-ruang Kelas. Jakarta : Grasindo.

Sanjaya, W. 2006. Strategi Pembelajaran Berorientasi Standar Proses Pendidikan. Jakarta : Kecana Prenada Media Group.

Slavin R. E. (2008). Coopertative Learning Teori, Riset, dan Praktik. Bandung : Nusa Media.

Surya, M, 2004, Psikologi Pembelajaran dan Fengajaran, Bandung : Pusta Bani Quraisy.

Trianto, 2007. Model-model Pembelajaran Inovaif Berorientasi Konstruktivitistik, Konsep, Landasan Teoritis-Praktis dan Implernentasinya. Jakarta : Prestasi Pustaka Publisher.

Uno, Masri Kuadrat. 2009. Mengelola Kecerdasan Dalam Pembelajaran, Jakarta: Bumi Aksara.

Winkel. 1989. Psikologi Pengajaran. Jakarta : Gramedia Widiasarana Indonesia. 